\title{
EDCTP regional networks of excellence: initial merits for planned clinical trials in Africa
}

\author{
George M Miiro ${ }^{1 * \dagger}$, Odile Ouwe Missi Oukem-Boyer ${ }^{2,5 \dagger}$, Ousmane Sarr ${ }^{3}$, Maerangis Rahmani ${ }^{4}$, Francine Ntoumi ${ }^{2,6}$, \\ Keertan Dheda ${ }^{4}$, Alexander Pym ${ }^{4}$, Souleymane Mboup ${ }^{3}$, Pontiano Kaleebu ${ }^{1}$ and On behalf of the NoEs' programme
}

\begin{abstract}
Background: Achieving the Millennium Development Goals (MDGs) and combating hotspots with escalating but preventable communicable diseases remain major challenges in Africa. The European and Developing Countries Clinical Trials Partnership (EDCTP) intervened to combat poverty-related diseases including malaria, tuberculosis and HIV/AIDS, and to conduct multi-centre clinical trials and multi-disciplinary health research through an innovative model of regional Networks of Excellence (NoEs).
\end{abstract}

Methods: We participated in a quasi-formative evaluation between October and December 2011 on the 4 regionalled research networks. These included the: Central Africa Network on Tuberculosis, HIV/AIDS and Malaria (CANTAM); East African Consortium for Clinical Research (EACCR); West African Network of Excellence for TB, AIDS and Malaria (WANETAM), and the Trials of Excellence for Southern Africa (TESA) launched between 2009 and 2010. We shared a participatory appraisal of field reports, progress reports and presentations from each network to jointly outline the initial experiences of the merits, outputs and lessons learnt.

Results: The self-regulating democratic networks, with 64 institutions in 21 African countries, have trained over 1 , 000 African scientists, upgraded 36 sites for clinical trials, leveraged additional $€ 24$ million and generated 38 peerreviewed publications through networking and partnerships.

Conclusions: The shared initial merits and lessons learnt portray in part the strengthened capacity of these networks for improved research coordination and conduct of planned multi-center clinical trials in Africa. Increased funding by African agencies, governments and international health partners will ensure sustainability of these networks for research capacity development and demonstrate their commitment to achieving the MDGs in Africa.

Keywords: Regional networks, Health, Clinical trials, Research, Capacity-building, Africa

\section{Background}

The Millennium Development Goals (MDGs) are described as ambitious for sub-Saharan Africa and are a real barometer to assess countries' efforts towards improving the health of populations [1]. These universal goals target, among other priorities, poverty-related diseases such as tuberculosis, malaria and HIV/AIDS. Although Africa bears the greatest burden of these three major diseases with potential for global transmission, the continent is characterized by weak and under-resourced health infrastructure, health interventions inappropriate

\footnotetext{
* Correspondence: gmmiiro@yahoo.co.uk

${ }^{\dagger}$ Equal contributors

'EACCR: The East African Consortium for Clinical Research, Uganda Virus

Research Institute, Plot 51-59 Nakiwogo, Entebbe, Uganda

Full list of author information is available at the end of the article
}

to the scale of the problem, and benefits of health not reaching those with the greatest disease burden $[2,3]$. In addition, African health research institutions are crippled by fragmentation, lack of coordination, diminishing critical mass of qualified African researchers, inadequate research infrastructure, and inconsistent and limited funding opportunities $[4,5]$. Such challenges hamper the contribution of African leadership to impact on research about diseases of global health importance.

To address some of these challenges, the European and Developing Countries Clinical Trials Partnership (EDCTP), a European Union-funded and peer-review grant awarding agency [6], initiated the concept of the regional Networks of Excellence (NoEs) led by African professionals [7] to champion capacity development, 
research excellence and networking, in partnership with European member states while concurrently contributing to the MDGs. Some of the MDGs addressed by 2015 include MDG4: reducing child mortality; MDG6: combating HIV/AIDS, TB, malaria and other diseases, and MDG8: developing global partnerships. Expected benefits of the regional NoEs include: a) sustainable multi-site research coordination and grant management capabilities, b) generating capacity for up scaling the number of qualified African scientists and health practitioners, c) securing infrastructure, partnerships and funds capable of responding efficiently to regional diseases and threats through synergy and multi-disciplinary collaboration. The strategic investment and contribution by the EDCTP to the four NoEs (Figure 1) for the conduct of multi-centre clinical trials and health research in Africa deserves particular appraisal [8].

The history and features of these networks are unique [9]. How were the networks formulated? Which strategies were developed by each network to achieve their objectives? How have these networks interacted? And finally what are some of the lessons learnt through the NoEs' programme? This joint introductory article addresses some of these key questions. Detailed results from each NoE will be subsequently published separately.

\section{Methods}

We participated in a quasi-formative evaluation of the NoEs between October and December 2011 through

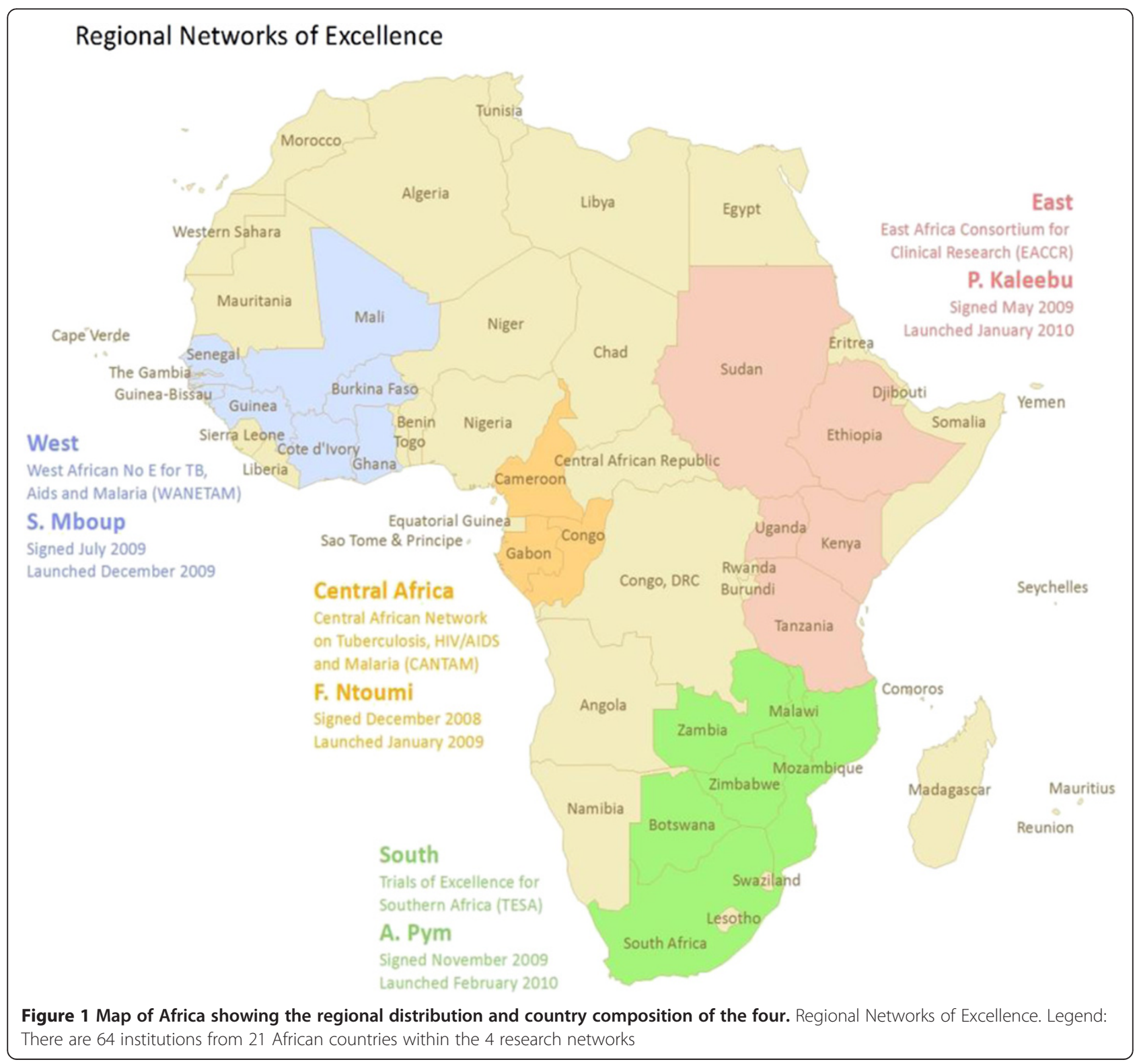


Table 1 Countries, institutions, diseases and members of the Networks of Excellence (NoEs) programme

\begin{tabular}{lll}
\hline NoE (Project Coordinator) & Country & Institution \\
\# of institutions & Disease
\end{tabular}

\begin{tabular}{|c|c|c|c|c|c|c|}
\hline \multirow[t]{7}{*}{$\begin{array}{l}\text { CANTAM (Francine } \\
\text { Ntoumi) } 7\end{array}$} & \multirow[t]{4}{*}{ Cameroon } & $\begin{array}{l}\text { Centre International de Référence } \\
\text { Chantal Biya (CIRCB) }\end{array}$ & \multicolumn{3}{|l|}{$x$} & $\begin{array}{l}\text { Odile Ouwe } \\
\text { Missi } \\
\text { Oukem-Boyer }\end{array}$ \\
\hline & & University of Yaoundé I & & $x$ & $x$ & $\begin{array}{l}\text { Rose Leke, } \\
\text { Veronique } \\
\text { Penlap }\end{array}$ \\
\hline & & University of Buea & $x$ & & $x$ & $\begin{array}{l}\text { Eric Achidi, } \\
\text { Peter Ndumbe }\end{array}$ \\
\hline & & OCEAC & & & $x$ & Parfait Awono \\
\hline & \multirow[t]{2}{*}{ Congo } & University Marien Ngouabi & $x$ & $x$ & $x$ & $\begin{array}{l}\text { Francine } \\
\text { Ntoumi, } \\
\text { Obengui }\end{array}$ \\
\hline & & CERVE & $x$ & & $x$ & $\begin{array}{l}\text { Mathieu } \\
\text { Ndounga }\end{array}$ \\
\hline & Gabon & Medical Research Unit of the Albert Schweitzer Hospital & $x$ & $x$ & $x$ & $\begin{array}{l}\text { Saadou } \\
\text { Issoufou }\end{array}$ \\
\hline \multirow{14}{*}{$\begin{array}{l}\text { EACCR (Pontiano Kaleebu) } \\
34 \text { (represented here by } 17 \\
\text { leading institutions }\end{array}$} & Sudan & $\begin{array}{l}\text { Institute of Endemic Diseases } \\
\text { (IEND), University of Khartoum }\end{array}$ & & $x$ & $x$ & $\begin{array}{l}\text { Mukhtar } \\
\text { Maowia }\end{array}$ \\
\hline & Ethiopia & Armauer Hansen Research Institute (AHRI) & $x$ & $x$ & & $\begin{array}{l}\text { Abraham } \\
\text { Aseffa }\end{array}$ \\
\hline & \multirow[t]{3}{*}{ Uganda } & Uganda Virus Research Institute (UVRI) & $x$ & & & $\begin{array}{l}\text { Edward } \\
\text { Katongole- } \\
\text { Mbidde, } \\
\text { Jonathan } \\
\text { Kayondo, Emily } \\
\text { Nyanzi }\end{array}$ \\
\hline & & $\begin{array}{l}\text { Medical Research Council (MRC) } \\
\text { Unit on AIDS in Uganda }\end{array}$ & $x$ & & & $\begin{array}{l}\text { Alison Elliott, } \\
\text { Heiner } \\
\text { Grosskurth }\end{array}$ \\
\hline & & $\begin{array}{l}\text { Makerere University and } \\
\text { Infectious Disease Institute }\end{array}$ & $x$ & & $x$ & $\begin{array}{l}\text { Elly Katabira, } \\
\text { Andrew } \\
\text { Kambugu }\end{array}$ \\
\hline & \multirow[t]{5}{*}{ Kenya } & $\begin{array}{l}\text { Kenya Medical Research Institute } \\
\text { (KEMRI)-Wellcome Trust Research Program }\end{array}$ & & & $x$ & $\begin{array}{l}\text { Norbert Peshu, } \\
\text { Peninah Soipei } \\
\text { Menza }\end{array}$ \\
\hline & & $\begin{array}{l}\text { Kenya Medical Research Institute } \\
\text { (KEMRI)-Walter-Reed Project }\end{array}$ & $x$ & & $x$ & $\begin{array}{l}\text { Bernhards } \\
\text { Ogutu }\end{array}$ \\
\hline & & $\begin{array}{l}\text { Kenya Medical Research Institute } \\
\text { (KEMRI)-Centre for Global Health Research in partnership with CDC }\end{array}$ & $x$ & $x$ & $x$ & Kayla Laserson \\
\hline & & $\begin{array}{l}\text { Kenya AIDS Vaccine Initiative } \\
\text { (KAVI)/University of Nairobi }\end{array}$ & $x$ & $x$ & & $\begin{array}{l}\text { Walter Jaoko, } \\
\text { Omu Anzala }\end{array}$ \\
\hline & & Maseno University & & & $x$ & Ayub Ofulla \\
\hline & \multirow[t]{4}{*}{ Tanzania } & $\begin{array}{l}\text { Kilimanjaro Christian Medical Centre (KCMC)/Kilimanjaro Clinical } \\
\text { Research Institute (KCRI) }\end{array}$ & $x$ & $x$ & $x$ & $\begin{array}{l}\text { Gibson Kibiki, } \\
\text { Frank Mosha, } \\
\text { Reginald } \\
\text { Kavishe }\end{array}$ \\
\hline & & Ifakara Health Institute $(\mid \mathrm{HI})$ & $x$ & $x$ & $x$ & $\begin{array}{l}\text { Salim Abdulla, } \\
\text { Seif } \\
\text { Shekaleghe, } \\
\text { Salim Nahya }\end{array}$ \\
\hline & & $\begin{array}{l}\text { National Institute for Medical Research } \\
\text { (NIMR)-Mwanza }\end{array}$ & $x$ & & & $\begin{array}{l}\text { John } \\
\text { Changalucha, } \\
\text { Mark Urassa }\end{array}$ \\
\hline & & $\begin{array}{l}\text { National Institute for Medical Research } \\
\text { (NIMR)-Tanga Research Centre }\end{array}$ & & & $x$ & $\begin{array}{l}\text { Martha } \\
\text { Lemnge }\end{array}$ \\
\hline
\end{tabular}


Table 1 Countries, institutions, diseases and members of the Networks of Excellence (NoEs) programme (Continued)

\begin{tabular}{|c|c|c|c|c|c|c|}
\hline & & $\begin{array}{l}\text { National Institute for Medical Research } \\
\text { (NIMR)-Mbeya Medical Research Programme }\end{array}$ & $x$ & $x$ & & $\begin{array}{l}\text { Leonard } \\
\text { Maboko, Lucas } \\
\text { Maganga }\end{array}$ \\
\hline & & Muhimbili University of Health and Allied Sciences & $x$ & $x$ & $x$ & $\begin{array}{l}\text { Eligius } \\
\text { Rwamuya, } \\
\text { Joyce Masalu }\end{array}$ \\
\hline & & National Institute for Medical Research (NIMR) -Muhimbili & $x$ & $x$ & & $\begin{array}{l}\text { Mwele } \\
\text { Malecera, } \\
\text { Sayoki } \\
\text { Mfinanga, } \\
\text { Bernard Ngowi }\end{array}$ \\
\hline \multirow[t]{10}{*}{ TESA (Alexander Pym) 10} & Botswana & Botswana Harvard HIV/AIDS Partnership (BHP) & $x$ & $x$ & & $\begin{array}{l}\text { Rosemary } \\
\text { Musonda }\end{array}$ \\
\hline & South Africa & $\begin{array}{l}\text { South African Medical Research Council: } \\
\text { Tuberculosis Research Unit (TBRU) }\end{array}$ & $x$ & $x$ & & Alexander Pym \\
\hline & & $\begin{array}{l}\text { Stellenbosch University Immunology } \\
\text { Research Group (SUN-IRG) }\end{array}$ & $x$ & $x$ & & Gerhard Walzl \\
\hline & & $\begin{array}{l}\text { University of Cape-Town Lung Institute } \\
\text { (UCT-LUNG) }\end{array}$ & & $x$ & & Keertan Dheda \\
\hline & & $\begin{array}{l}\text { University of Cape Town- Division of } \\
\text { Clinical Pharmacology (UCT-PHARM) }\end{array}$ & $x$ & $x$ & & $\begin{array}{l}\text { Helen } \\
\text { Mcllleron }\end{array}$ \\
\hline & Zimbabwe & University of Zimbabwe College of Health Sciences (UZ-CHS) & $x$ & & & Lynn Zijenah \\
\hline & & Biomedical Research and Training Institute (BRTI) & $x$ & $x$ & & Peter Mason \\
\hline & Zambia & University of Zambia -University Teaching Hospital (UN-ZAM) & $x$ & $x$ & $x$ & $\begin{array}{l}\text { Peter Mwaba, } \\
\text { Duncan } \\
\text { Chanda }\end{array}$ \\
\hline & Malawi & Malawi College of Medicine (Malawi- CoM) & $x$ & & $x$ & $\begin{array}{l}\text { Newton } \\
\text { Kumwenda }\end{array}$ \\
\hline & Mozambique & Centro de Investigacao em Saude da Manhica (CISM) & $x$ & $x$ & $x$ & $\begin{array}{l}\text { Eucebio } \\
\text { Macete }\end{array}$ \\
\hline \multirow[t]{13}{*}{$\begin{array}{l}\text { WANETAM (Souleymane } \\
\text { Mboup) } 13\end{array}$} & Senegal & Laboratory of Bacteriology-virology, A. Le Dantec Hospital (UCAD) & $x$ & $x$ & & $\begin{array}{l}\text { Souleymane } \\
\text { Mboup }\end{array}$ \\
\hline & & Institut Pasteur, Dakar & & & $x$ & Aissatou Toure \\
\hline & The Gambia & National Public Health Laboratories & $x$ & & & Makei Taal \\
\hline & & Medical Research Council, Fajara The Gambia & $x$ & $x$ & $x$ & $\begin{array}{l}\text { Tumani Corrah/ } \\
\text { Martin Antonio }\end{array}$ \\
\hline & $\begin{array}{l}\text { Guinea } \\
\text { Bissau }\end{array}$ & Project de Saude de Bandim & & $x$ & & Paulo Rabna \\
\hline & Nigeria & College of Medicine University of Ibadan & & $x$ & & $\begin{array}{l}\text { Aderemi } \\
\text { Kehinde }\end{array}$ \\
\hline & & Nigerian Institute of Medical Research & & $x$ & & Oni Idigbe \\
\hline & & Innovative Biotech & $x$ & & & Simon Agwale \\
\hline & Ghana & $\begin{array}{l}\text { Korle-bu Teaching Hospital University of } \\
\text { Ghana Medical School }\end{array}$ & & $x$ & & Audrey Forson \\
\hline & & Noguchi Memorial Institute for Medical Research & & & $x$ & $\begin{array}{l}\text { Kwado Koram/ } \\
\text { Nancy Duah }\end{array}$ \\
\hline & Mali & Malaria Research and Training Center, Faculty of Medicine Bamako & & & $x$ & $\begin{array}{l}\text { Ogobara } \\
\text { Doumbo/ } \\
\text { Mahamadou } \\
\text { Thera }\end{array}$ \\
\hline & Burkina Faso & $\begin{array}{l}\text { Centre National de Recherche et de Formation sur le Paludisme, } \\
\text { Ouagadougou }\end{array}$ & & & $x$ & $\begin{array}{l}\text { Sodiomon } \\
\text { Sirima/ Issa } \\
\text { Nebie }\end{array}$ \\
\hline & & Centre Muraz & $x$ & $x$ & & $\begin{array}{l}\text { Jean B } \\
\text { Ouedraogo/ } \\
\text { Nicolas Meda }\end{array}$ \\
\hline
\end{tabular}


participatory appraisal methods of direct observation, retrospective review of field reports, meeting presentations and formal reports to EDCTP at the $6^{\text {th }}$ EDCTP forum [10]. We outline the experienced effects and initial merits of the four African NoEs in terms of governance, baseline studies, capacity building, networking, research outputs, and ability to leverage further funding under this newly introduced model.

\section{Results}

We outline below the results of each network (NOE) by the key reporting areas mentioned above.

\section{CANTAM (www.cantam.org)}

\section{A1. Project management}

This West African-led network has 7 institutions from 3 African countries (Cameroon, Congo and Gabon, Table 1). Its governance relies on a steering committee, with one representative from each institution, responsible for all crucial decisions. This steering committee appoints a project coordinator at the secretariat in Congo who is in charge of the daily management of the network, assisted by two project managers from Gabon and Cameroon.

\section{A2. Baseline studies}

The sister institutions in Congo and Cameroon have developed assessment surveys, while Gabon plays a leading role, with the Medical Research Unit in Lambaréné, already conducting clinical trials on malaria. By combining initial baseline studies and senior fellowship projects awarded to NoEs, CANTAM is better prepared to conduct future clinical trials in Cameroon (around Buea for HIV/AIDS, in Yaounde and Mbalmayo for tuberculosis, and in Niete and Mutengene for malaria) and Congo (all sites are in Brazzaville).
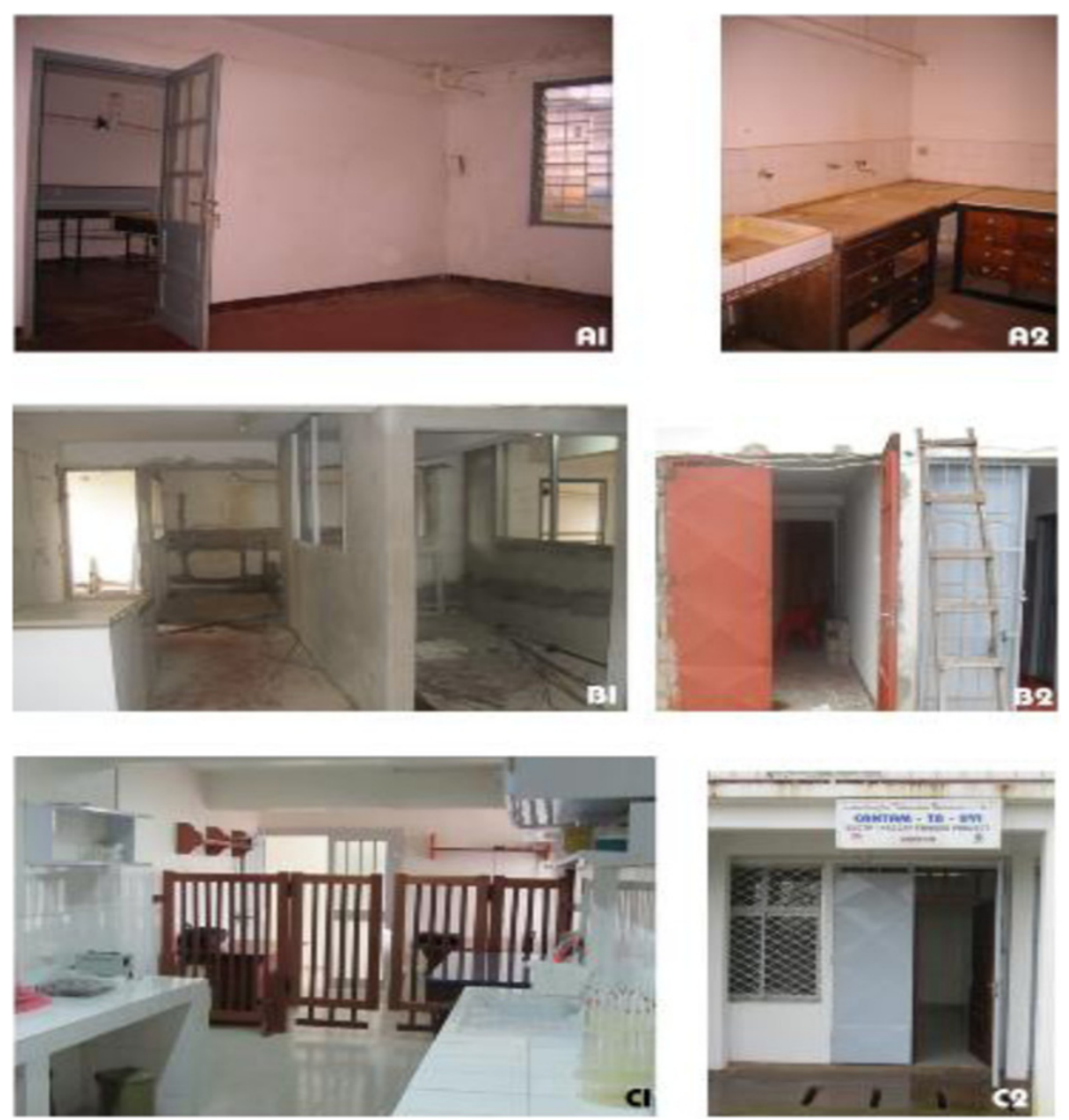

Figure 2 An example of laboratory refurbishment in Central Africa (University of Yaoundé 1, Cameroon). Legend: Old laboratory of the University of Yaoundé l, given to CANTAM in 2009 (A1, A2), laboratory under renovation in 2009-2010 (B1, B2); and refurbished laboratory with EDCTP/NACCAP funds $(\mathrm{C} 1, \mathrm{C} 2)$ in 2011 


\section{A3. Capacity building}

Concerted effort has been put into capacity building: laboratory upgrades (at the University Marien Ngouabi and Makelekele hospital in Brazzaville, Congo and Buea and Yaoundé I universities in Cameroon; Figure 2); long -term training of masters, $\mathrm{PhD}$, post-doctoral and medical students and cross-cutting specific and shortterm courses, including grant writing, ethics and Good Clinical Laboratory Practice (GCLP) (Table 2). Longterm training and appropriate mentorships are essential, especially in Congo, where there is an acute shortage of human resources in all disciplines [11].

\section{A4. Networking}

CANTAM has developed relationships within its network, and with local, regional and international organizations, which have resulted into field mentorships, shared training and joint seminars. Although North-south partnerships are essential in education (via 'sandwich' $\mathrm{PhD}$ programmes), technology transfer and joint grant writing, special attention has also been given to South-South partnerships, with emphasis on interactions with other networks for complementarity, synergy and greater impact. For example, EACCR facilitated short courses and mentorships for about 10 CANTAM students.

\section{A5. Advocacy}

EDCTP and CANTAM have been promoted through publications, international conferences and meetings, and networking with foreign and other organizations. Publications from CANTAM are increasing its visibility [11,12]. In Congo, Cameroon, and very recently in Gabon, EDCTP site visits were excellent opportunities for high-level advocacy and resource mobilization among prime ministers, ministers of higher education and of public health from each country.

\section{A6. Funding}

CANTAM received initial funding of $€ 2,997,644$ from the EDCTP and Netherlands-African Partnership for Capacity development and Clinical interventions Against Poverty-related diseases (NACCAP). Through the EDCTP, additional funding has been awarded to CANTAMaffiliated institutions, including three senior fellowships linked to NoEs, a re-entry grant, and two grants for bioethics and regulatory strengthening. In addition, Total Congo agreed to support research on malaria and severe diarrhea. Paraxel plans to conduct a clinical trial in one of CANTAM's malaria sites in Cameroon. Finally, an EDCTP-sponsored clinical trial is being conducted in Gabon as an integrated project on malaria. Overall, CANTAM received $€ 5,238,000$, including additional funds leveraged, for preparing clinical trial sites and conducting clinical research/trials, of which $78 \%$ is from EDCTP (Table 2).

\section{EACCR (www.eaccr.org)}

\section{B1. Project management}

This East African-led network has 34 regional institutions from Kenya, Tanzania, Uganda, Sudan and Ethiopia (Figure 1, Table 1) and 7 northern partners from Europe. Governance is structured regionally into 4 coordinating centers (nodes): malaria (Kenya), TB (Tanzania), HIV (Uganda) and training (Tanzania), which report to the overall project coordinator. The coordinator reports to an independent steering committee (with directors of leading regional institutions and representatives of northern partners) and to EDCTP. Meetings occur regularly through teleconferences, and face-to-face interaction.

\section{B2. Baseline studies}

Nodes conducted site assessment surveys on existing regional capabilities for training/mentoring and also prioritized infrastructural upgrades among 17 sister institutions for research and health.

Table 2 Selected outputs from the Networks of Excellence (NoEs) by the end of 2011

\begin{tabular}{|c|c|c|c|c|c|c|c|c|c|}
\hline \multirow[t]{2}{*}{ NoE } & \multicolumn{6}{|c|}{ Type of training (number of participants are listed) } & \multirow{2}{*}{$\begin{array}{c}\text { Funds }(€) \\
\text { leveraged } \\
-\end{array}$} & \multirow{2}{*}{$\begin{array}{c}\text { Number of } \\
\text { publications \# } \\
-\end{array}$} & \multirow{2}{*}{$\begin{array}{c}\text { Number of sites } \\
\text { upgraded }\end{array}$} \\
\hline & $\begin{array}{l}\text { Short } \\
\text { term* }\end{array}$ & $\begin{array}{l}\text { Diploma/ } \\
\text { BSc }\end{array}$ & MSc & $\mathrm{PhD}$ & $\begin{array}{l}\text { Post } \\
\text { Doc }\end{array}$ & Fellowship** & & & \\
\hline CANTAM & 83 & - & 6 & 8 & - & 4 & $1,152,360$ & 8 & 4 \\
\hline EACCR & 169 & - & 24 & - & - & 4 & $1,400,000$ & 1 & 19 \\
\hline TESA & 539 & 3 & 12 & 5 & 3 & 2 & $20,000,000$ & 29 & 10 \\
\hline WANETAM & 175 & - & 2 & 1 & - & 2 & $1,706,000$ & 0 & 3 \\
\hline Total & 966 & 3 & 44 & 14 & 3 & 12 & $24,258,360$ & 38 & 36 \\
\hline
\end{tabular}

* these include: GCP, GCLP, laboratory techniques, IT, ethics, grant writing, epidemiology, biostatistics, molecular biology, immunology, public health, clinical trials, parasitology and entomology.

** these are EDCTP sponsored senior fellowships which are affiliated to the NoEs.

\# Selected publications have been referenced below due to space considerations but the full list of all publications is available on request. 


\section{B3. Capacity building}

\section{Short-term training}

Four accessible user-friendly electronic learning research modules were developed and uploaded onto the EACCR website in partnership with the University of Oxford, Global Health Trials, World-Wide Anti-malarial Resistance Network (WWARN), and the Bill and Melinda Gates Foundation. Plans are underway to translate the modules into French for improved accessibility and greater impact. EACCR also conducted short courses in epidemiology, medical statistics, clinical trial monitoring and tropical immunology in partnership with the London School of Hygiene and Tropical Medicine (LSHTM), University of Cambridge and the Wellcome Trust (Table 2). Thus, regular courses are available at a highly subsidized fee or through partial competitive scholarships.

\section{Long-term training}

Four competitive EDCTP senior-fellowships were secured for promising research in Malaria (1), TB (1) and HIV/AIDS (2) between November 2009 and November 2010. In addition, 24 masters research fellowships have been sponsored (Table 2), 7 of which are pursued online.

\section{Reciprocal clinical monitoring scheme}

More than 20 regional monitors are conducting crosssite paired mentoring visits using standardized operating procedures. Shared best clinical monitoring practices are observed by new/upcoming monitors paired to experienced monitors [13]. Consultancy services are available at a negotiable fee for tailored trial training and monitoring.

\section{B4. Networking}

Participatory evaluation of the quality and bioethics of 2 research-monitoring schemes in East Africa and Asia is underway in partnership with WWARN and LSHTM. Furthermore, three EACCR's fellows on masters degree training secured more research funding through highly competitive scholarships from a Wellcome Trust Consortium-Training Health Researchers in Vocational Excellence THRiVE (www.thrive.or.ug).

\section{B5. Advocacy}

EACCR members shared thirty scientific presentations and abstracts at international meetings. This group interacted with other consortia such as Tuberculosis Vaccine Trials in Europe and Africa, TB-TEA (www. mpiib-berlin.mpg.de), CANTAM and THRiVE. In addition, contacts were initiated with policy-makers of the East African Community by EDCTP [14].

\section{B6. Funding}

EACCR is funded by EDCTP with co-funding from NACCAP and the Medical Research Council-United Kingdom (MRC-UK) at a level of $€ 3.5$ million. About $€ 1.4$ million in additional funds have been leveraged from other sources, such as Global Health Trials, WWARN, Wellcome Trust and the International Association of National Public Health Institutes (Table 2). To sustain its activities, this network has submitted for funding at least 5 collaborative grants on research coordination, HIV prevention research, and rapid TB diagnostics.

\section{TESA (www.tesafrica.org)}

\section{C1. Project management}

This South African-led network has 10 institutions across 6 countries including Botswana, Malawi, Mozambique, South Africa, Zambia and Zimbabwe, supported by the EDCTP through the South African Medical Research Council (SA-MRC) TB Research Unit. TESA currently supports, on a part- or full- time basis, between 40-50 scientists, clinicians, nurses and laboratory technologists.

\section{C2. Baseline studies}

Through the network's capacity development strategy, TESA-network institutions have initiated several HIV, $\mathrm{TB}$ and malaria studies (some of which have been published [15-22]), either at individual sites or jointly within multiple sites. These studies include:

- Changes in plasma cytokine levels over time during chronic asymptomatic HIV-1c Infection, an indicator of disease progression

- Rifaquin trial in newly diagnosed TB cases, Pharmaco-Kinetic studies, and molecular studies using isolates from cases of treatment failure or reinfection, and suspected multi-drug resistant-TB $[16,18,20]$

- HIV-1 incidence rate among patients with sexually transmitted infections

- Diagnostic and biomarker studies in those patients with suspected TB

- Epidemiological, microbiological, clinical and socioeconomic studies of re-treated TB patients

- Intensive case finding to determine the prevalence of drug sensitive and resistant-TB among those patients with suspected TB

- Accuracy and impact studies of Gene Xpert and newer diagnostic techniques including the urinary lipoarabinomannan strip test $[15,17,19,21]$

- Studies about the burgeoning drug-resistant TB epidemic and therapeutically destitute cases of drug resistant $\mathrm{TB}$ 


\section{C3. Capacity building}

Following advertisement of courses on the TESA website, trainees and students were selected based on the institutions' internal training policies, research projects and availability of research grants. Within the past two years more than 500 clinical research staff affiliated to TESA received short-courses training in internal auditing and quality control, International Air Transport Association-IATA training, HIV, TB and malaria laboratory diagnostic techniques, and methodological courses including the epidemiological, clinical and operational research course; qualitative research methods course; information technology, software training; workshops on Good Clinical Practices and bioethics; and seminars on scientific and grant writing skills, and biostatistics (Table 2).

As part of TESA's long-term capacity development program, 25 scientists are studying in various universities at masters, $\mathrm{PhD}$ and post-doctoral level (Table 2).

Three TB, HIV and malaria laboratories within TESA institutions have been accredited and a further three laboratories are in the process of accreditation. Two research training facilities and one clinical research site have been upgraded and most laboratories were refurbished with basic equipment and information technology support systems.

\section{C4. Networking}

The networking within TESA has taken various forms including, i) student visits and attendance in cross country courses, ii) scientific presentations at national and international conferences and forums iii) attendance of regular national and regional technical meetings by investigators with the national departments of health, science councils, and academia, iv) linkages with national regulatory authorities and v) liaisons with European science councils, pharmaceuticals, donors and funding agencies.

\section{C5. Advocacy}

The design and operationalization of the TESA Website in May 2010 facilitated above networking activities, communication and circulation of information about activities and courses, and linkage with international organizations.

\section{C6. Funding}

TESA received $€ 2.3$ million in November 2009 from EDCTP, followed by additional in-kind contribution of $€$ 280,000 from SA-MRC. However, most TESA sites have since developed new research proposals, which to date have attracted an additional $\sim € 20$ million in research grants and contracts (Table 2).

\section{WANETAM (www.edctp.org/project_profiles.245.0.html) D1. Project management}

WANETAM established 6 Work Packages (project management, training, networking, HIV-related training and survey, TB-related training and survey, and malaria related training and survey). Work package leaders and the project manager constituted the steering committee, chaired by the project coordinator. This committee meets every other month by teleconference to review progress in capacity-building and training. The coordinator is responsible for submitting annual technical and expenditure reports to the EDCTP. The responsibility for individual projects (resources, research and meeting milestones) was devolved to site Principal Investigators, who interact directly with Work Package leaders to produce written reports. WANETAM also has an independent advisory board, whose role is to advise the steering committee on the evolution of important activities.

\section{D2. Baseline studies}

WANETAM did not initially include baseline studies. However, through the second annual meeting, submission of a revised work plan for year 3 and the subsequent re-allocation of funds, the principal investigators agreed to carry out HIV/AIDS, tuberculosis, and malaria baseline surveys as a sustainability strategy.

\section{D3. Capacity building}

From January 2011 to June 2011 WANETAM trained 175 West African junior and senior scientists in clinical trial-related topics (Table 2) and disease-specific laboratory training organized by different partner institutions. Moreover, laboratories at Korle-bu (Ghana), and Guinea-Bissau have been refurbished. Specific equipment has been purchased for TB-associated laboratories while other laboratories have received equipment for hematology or biochemistry studies.

\section{D4. Networking}

The secretariat has hosted two annual meetings of the principal investigators, which addressed the critical challenges that WANETAM has encountered (such as the initial omission of baseline studies and sustainability). The group has also established exchange and mentorship programmes between institutions. Additional networking has led to more funding through WANETAM Plus (constituted by WANETAM-TB institutions plus other institutions from Benin, Mali and Burkina Faso), and WAPHIR (West African Platform for HIV Intervention). Furthermore, joint study proposals have been submitted to the Trilateral Initiative (Germany, France, and WANETAM), and Framework Programme 7 of the European Commission grant call. 


\section{D5. Advocacy}

WANETAM created an efficient and reliable communication environment. Through a web-based platform called Basecamp, members can share information of interest, work on the same document, and discuss activities of the consortium (https://wanetamproject.basecamphq. com). Recently, the consortium has implemented a Voice on IP teleconference system allowing free communication among the partners. Prior to this, WANETAM created its website which is open to the public. In addition to the above communication strategies, WANETAM distributes regular newsletters.

\section{D6. Funding}

Overall, the EDCTP contributed $€ 3,499,921$. Of this, NACCAP, MRC-UK, and MRC-Gambia contributed $€ 1,000,000, € 406,000$, and $€ 300,000$ respectively.

\section{Discussion}

The 4 NoEs described above, with 64 institutions from 21 African countries are African-led, multi-disciplinary, and multi-disease-oriented (Figure 1, Table 1). They are comparable to the subsequent Wellcome Trust initiative comprising 7 consortia which interlink 52 institutions from 18 African countries [23,24]. In contrast, the Malaria Capacity Development Consortium, Multilateral Initiative on Malaria and the ALPHA network have a single-disease orientation [25-27].

Robust and democratic governance structures are essential for the success of such networks [24]. The EDCTP NoEs have created described governance structures for self-regulation. The initial achievements and lessons learnt are discussed below. It is challenging to devise generic indicators for monitoring and evaluating capacity building since each project is unique [28]. Like other consortia [25-27], we predominantly referred to initial output-based (lower process) indicators from a donor reporting format such as number of fellowships sponsored, number of participants trained (Table 2), and number of facilities upgraded. We also attempted to include higher outcome indicators $[5,25,27,28]$ such as amount of additional funds leveraged from alternative sources and number of publications. Over time, we shall track and include the number of $\mathrm{PhD}$ and doctoral fellows retained in Africa, and the number of policy outcomes. This paper contributes to further discussion of suitable indicators of progress for inclusion in subsequent monitoring and evaluation initiatives.

\section{Project management}

Each network has a governance structure for better research coordination and resource sharing across Anglophone, Lusophone and Francophone countries in Africa. Another distinct feature of these NoEs is that consultative strategic planning processes were self-led rather than being dictated by the EDCTP. Thus, each NoE and partner institutions had the flexibility to adopt appropriate research capacity development activities well aligned to their preferences.

\section{Baseline studies}

The NoEs opted to conduct baseline studies for two main reasons linked to sustainability strategies. First, they constitute a practical prerequisite for the conduct of clinical trials in future. Second, in terms of visibility, these studies are publishable aspects of the research activities for each NoE.

\section{Capacity building}

NoEs have invested substantially in clinical trial infrastructure and in education, through specific or crosscutting short-term training, long-term training, and/or field mentorships to produce networked high-skilled African researchers. Stronger research institutions have been coupled with upcoming ones for on-going mentoring. However, results will take years to be measured, especially in Central Africa, where a critical mass of scientists is nascent and the culture of research is still dramatically lacking. Some NoEs experienced challenges in grant management, including inadequate prior establishment of monitoring and evaluation systems and delayed disbursement of funds. For instance, it was extremely difficult for EACCR to disburse funds to Sudan, possibly because of political concerns there. Some observed gaps in grant management should be filled with additional training and technical assistance in project and financial management.

\section{Networking}

First, institutions within each NoE have learnt to collaborate in joint proposal development and project implementation, including budget sharing while avoiding duplication of effort. Second, regional NoEs have developed enriching relationships among themselves. EACCR welcomed CANTAM students and staff for short-term training on several occasions, thus reinforcing the links between institutions from the different NoEs. However, more initiatives engaging all the four NoEs should be encouraged. Third, all NoEs have interacted with various networks, organizations or northern partners, including WWARN, Global Health Trials, THRiVE, Initiative to Strengthen Research Capacity in Africa, Africa AIDS Vaccine Partnership and the African Network on Drugs and Diagnostics Innovation among others. More importantly and for purposes of sustainability, the networks are strongly encouraged to engage the policy-makers and the pharmaceutical industry to: inform policies and 
financing, drive health product development, best health practices and interventions [4,5,29-32].

\section{Advocacy}

All four NoEs created their own websites to strengthen communication, interaction, advertising of training opportunities, sharing of pictures related to specific activities of the networks, and listing publications derived from research activities. Publications in peer-reviewed journals derived from baseline studies will enable each $\mathrm{NoE}$ to gain more visibility and credibility for sustainability.

However, frequent Internet disconnections are challenging. Communication can be improved through better Internet connectivity as recently developed by WANETAM and through more efficient video conferencing and webinar series.

\section{Funding}

The networks have made concerted effort to leverage additional funds from alternative sources for their sustainability. TESA has performed superbly in attracting a 10 -fold increase in additional funds from the baseline grant awarded by the EDCTP. Other networks are encouraged to emulate this sustainability strategy.

\section{Conclusion}

The most rewarding experience emerging from this initiative is that the 4 networks have great potential to contribute synergistically to the attainment of the MDG 4, 6 , and 8 in Africa, which focus on reduction of child mortality, combating HIV/AIDS, malaria, and other diseases for development as emphasized by a similar initiative by Wellcome Trust [24,29]. For sustainability, the NoEs recommend i) financing of streamlined career pathways, such as re-entry grant fellowships and competitive scientific awards for productive retention of young and promising African scientists, and ii) increased financial support from the African funding agencies and African governments [5,29-32] in the context of country- and regional-owned initiatives to facilitate faster progress towards achieving the MDGs on the continent.

\section{Competing interest}

Co-authors contributed to both the implementation and the quasi-appraisal of the research networks.

\section{Authors' contributions}

All authors except OOMOB participated in the discussions at the $6^{\text {th }}$ EDCTP Forum, where the writing up of this manuscript was adopted. OOMOB and FN, GM, OS, MR and KD drafted the CANTAM, EACCR, WANETAM and TESA sections respectively. GM and $O O M O B$ contributed equally in coordinating the writing team; crosschecking the methods section and references cited; collating and harmonizing the different manuscript versions leading to the final version. DK gave conceptual advice and additional technical support in writing this paper and PK made critical contributions during the writing process. OOMOB, FN, GM, OS, MR and KD edited and reviewed the various drafts of the manuscript. All authors approved the final version.
Authors' information

The annexed team of the NoEs' programme in Table 1, sponsored by the European and Developing Countries Clinical Trials Partnership (EDCTP).

\section{Acknowledgement}

The authors acknowledge greatly the visionary, guiding and enabling contributions of EDCTP and like-minded organizations (such as the European Commission, NACCAP and MRC-UK) towards the conception, initiation and initial achievements of the Networks of Excellence (NoEs) programme. In particular, the authors applaud the leadership, governance and constituencies of EDCTP (i.e. the General Assembly, Partnership Board, Developing Countries Coordinating Committee and the Cape Town Office) for their highly enhancing and synergizing roles and advocacy for the largescale innovative, capacity-strengthening and networked African-led research consortia. We are also grateful to the leadership, all members and partners (in the north and south) of the 4 NoEs for providing their infrastructure, experience, expertise, the enduring and very supportive engagement under this evolving, transformative and rewarding EDCTP initiative. Dr. Thomas Nyirenda (of EDCTP Cape Town Office), Dr. Allison Greenspan (of IANPHI) and other members of the NoEs are acknowledged for peer-reviewing this manuscript and giving valuable contribution.

\section{Author details}

'EACCR: The East African Consortium for Clinical Research, Uganda Virus Research Institute, Plot 51-59 Nakiwogo, Entebbe, Uganda. ${ }^{2}$ CANTAM: The Central African Network for Tuberculosis HIV/AIDS and Malaria, Fondation Congolaise pour la Recherche Médicale, University Marien Ngouabi, Brazzaville, Republic of Congo. ${ }^{3}$ WANETAM: The West Africa Network of Excellence for TB, AIDS and Malaria Laboratoire de Bacteriologie-virologie CHU Aristide Le Dantec, Universite Cheikh Anta Diop, Dakar, Senegal. ${ }^{4}$ TESA The Trials of Excellence for Southern Africa, Medical Research Council South Africa- TB Research Unit: Clinical and Biomedical, Durban, South Africa. ${ }^{5}$ Centre de Recherche Médicale et Sanitaire (CERMES), Niamey, Niger. ${ }^{6}$ The Institute for Tropical Medicine, University of Tubingen, Germany.

Received: 6 September 2012 Accepted: 14 March 2013

Published: 22 March 2013

\section{References}

1. United Nations: United Nations Millennium Project: Goals and targets. 2012. accessed on 20th May 2012: www.unmillenniumproject.org/reports/ goals_targets.htm.

2. African Union: Assessing progress in Africa towards the millennium development goals. 2006. accessed on 21st May 2012: www.african-union. org.

3. Kilama WL: The 10/90 gap in sub-Saharan Africa: Resolving inequities in health research. Acta Trop 2009, 112S:S8-s15.

4. Whitworth JA, Kokwaro G, Kinyanjui S, et al: Strengthening capacity for health research in Africa. Lancet 2008, 372(9649):1590-1593.

5. Zumla A, Huggett J, Dheda K, Green C, et al: Trials and tribulations of an African-led research and capacity development programme: the case for EDCTP investments. TMIH 2010, 15(4):489-494.

6. Matee MI, Manyondo C, Ndumbe PM, et al: European and Developing Countries Clinical Trials Partnership (EDCTP): the path towards a true partnership. BMC Publ Health 2009, 9:249.

7. Kitua AY, Corrah T, Herbst K, et al: Strengthening capacity, collaboration and quality of clinical research in Africa: EDCTP Networks of Excellence. Tanzanian J Health Res 2009, 11:51-54.

8. Dolgin E: African networks launch to boost clinical trial capacity. Nat Med 2010, 16(1):8. ISSN 1546-170X (Electronic) 1078-8956 (Linking).

9. Netherlands-African: Partnership for Capacity development and Clinical interventions Against Poverty-related diseases (NACCAP). 2011: NACCAP 20042011: Lessons learned 2011; 2011:25-27. Accessed on 11th June 2012: http://www.nwo.nl/en/about-nwo/media-and-communication/publications/ wotro/naccap-2004-2011-lessons-learned.html.

10. Mgone CS, Makanga M: Strengthening research partnerships for better health and sustainable development. TMIH 2012, 17(l):1-82.

11. Ntoumi F: Networking and capacity building for health research in Central Africa. Wien Klin Wochenschr 2010, 122(1):23-26. ISSN 1613-7671 (Electronic) 0043-5325 (Linking). 
12. Ntoumi F: The ant who learned to be an elephant. Science 2011, 333(6051):1824-1825. ISSN 1095-9203 (Electronic) 0036-8075 (Linking).

13. Chilengi $R$, Ogetti $G$, Lang $T$ : A sensible approach to monitoring trials: finding effective solutions in-house. WebmedCentral Clinical Trials 2010, 1(10), WMC00891.

14. EDCTP: EAC Health Ministers sixth annual meeting in the Republic of in Burundi: Participation in EDCTP programme encouraged. 2011. accessed on 11th June 2012 at: http://www.edctp.org/fileadmin/documents/ EDCTP_news_-_EAC_Health_Ministers_sixth_annual_meeting_in_Burundi. pdf.

15. Theron G, Peter J, Lenders L, van Zyl-Smit R, Meldau R, Govender U, Dheda $\mathrm{K}$ : Correlation of mycobacterium tuberculosis specific and non-specific quantitative Th1 T-cell responses with bacillary load in a high burden setting. PLoS One 2012, 7(5):e37436. Epub 2012 May 22. PMID: 22629395 [PubMed - in process].

16. Mcllleron $\mathrm{H}$, Willemse $\mathrm{M}$, Schaaf HS, et al: Pyrazinamide plasma concentrations in young children with tuberculosis. Pediatr Infect Dis $J$ 2011, 30(3):262-265.

17. Peter JG, Theron G, van Zyl-Smit R, Haripersad A, Mottay L, Kraus S, Binder A Meldau R, Hardy A, Dheda K: Diagnostic accuracy of a urine LAM strip-test for TB detection in HIV-infected hospitalised patients. Eur Respir J 2012 [Epub ahead of print]. PMID: 22362849 [PubMed - as supplied by publisher].

18. Sinxadi PZ, Van Der Walt JS, Mcllleron HM, et al: Lack of association between stavudine exposure and lipoatrophy, dysglycaemia, hyperlactataemia and hypertriglyceridaemia: a cross-sectional study. AIDS Res Ther 2010, 7(1):23.

19. van Zyl-Smit RN, Binder A, Meldau R, Mishra H, Semple PL, Theron G, Peter J, Whitelaw A, Sharma SK, Warren R, Bateman ED, Dheda K: Comparison of quantitative techniques including Xpert MTB/RIF to evaluate mycobacterial burden. PLoS One 2011, 6(12):e28815. Epub 2011 Dec 22. PMID: 22216117 [PubMed - indexed for MEDLINE].

20. Ma Z, Lienhardt C, Mcllleron HM, et al: Global tuberculosis drug development pipeline: the need and the reality. Lancet 2010, 375:2100-2109.

21. Theron G, Pinto L, Peter J, Mishra HK, Mishra HK, van Zyl-Smit R, Sharma SK, Dheda K: The use of an automated quantitative polymerase chain reaction (Xpert MTB/RIF) to predict the sputum smear status of tuberculosis patients. Clin Infect Dis 2012, 54(3):384-388. Epub 2011 Dec 1. PMID: 22139854 [PubMed - indexed for MEDLINE]

22. Mehta U, Allen E, Barnes Kl, et al: Establishing pharmacovigilance programs in resource-limited setting: the example of treating malaria. Expert Rev Clin Pharmacol 2010, 3:509-525.

23. Editor: Strengthening research capacity in Africa. Lancet 2009, 374:1. accessed on 11th June 2012 at www.thelancet.com.

24. Marjanovic S, Hanlin R, Diepeveen S, Chataway J: Research capacity building in Africa: networks, institutions and local ownership. The Wellcome Trust. Open Research Online 2012. 2012. Accepted manuscript accessed on 3rd July 2012 at: http://dpp.open.ac.UK/research/projects/scientific-capacity-building-africa.

25. Greenwood B, Bhasin A, Targett G: The Gates Malaria Partnership: a consortium approach to malaria research and capacity development. TMIH 2012, 17(5):558-563.

26. Rugemalila JB, Ogundahunsi OA, Stedman TT, Kilama WL: Multilateral initiative on malaria: justification, evolution, achievements, challenges, opportunities, and future plans. AmJTrop Med Hyg 2007, 77(6):296-302.

27. Maher D, Biraro S, Hosegood V, et al: Translating global health research aims into action: the example of the ALPHA network. TMIH 2010, 15(3):321-328.

28. World Bank: Capacity building in Africa: an OED evaluation of World Bank Support. Washington, DC: The World Bank; 2005. accessed 11th June 2011 (Inweb90.worldbank.org/oed/oeddoclib.nsf/ 24cc3bb1f94ae11c85256808006a0046/5676a297fe57caf685256fdd00692e32/ \$file/africa_capacity_building.pdf).

29. Ezeh AC, Izugbara CO, Kabiru CW, et al: Building Capacity for public and population health research in Africa: the consortium for advanced research training in Africa (CARTA) model. Global Health Action 2010, 3:5693. doi:DOI: 10.3402/gha.v3i0.5693.
30. Al-Bader S, Masum H, Simiyu K, et al: Science-based health innovation in sub-Saharan Africa. BMC Int Health Human Rights 2010, 10(Suppl 1):S1.

31. Satcher R, Evans-Storms RB, Rouse DJ, et al: Enabling infrastructure for global health product development. Drug Discov Today 2012. Jun 1 [Epub ahead of print].

32. Goldberg J, Bryant M: Country ownership and capacity building: the next buzzwords in health systems strengthening or a truly new approach to development. BMC Publ Health 2012, 12:531. www.biomedcentral.com/ $1471-2458 / 12 / 531$

\section{doi:10.1186/1471-2458-13-258}

Cite this article as: Miiro et al:: EDCTP regional networks of excellence: initial merits for planned clinical trials in Africa. BMC Public Health 2013 $13: 258$

\section{Submit your next manuscript to BioMed Central and take full advantage of:}

- Convenient online submission

- Thorough peer review

- No space constraints or color figure charges

- Immediate publication on acceptance

- Inclusion in PubMed, CAS, Scopus and Google Scholar

- Research which is freely available for redistribution

Submit your manuscript at www.biomedcentral.com/submit
C Biomed Central 